\title{
Assessing exhibition swine as potential disseminators of infectious disease through the detection of five respiratory pathogens at agricultural exhibitions
}

\author{
Sarah E. Lauterbach', Sarah W. Nelson ${ }^{1}$, Meghann E. Robinson², Josh N. Lorbach', Jacqueline M. Nolting ${ }^{1}$ \\ and Andrew S. Bowman ${ }^{1 *}$ (1)
}

\begin{abstract}
Widespread geographic movement and extensive comingling of exhibition swine facilitates the spread and transmission of infectious pathogens. Nasal samples were collected from 2862 pigs at 102 exhibitions and tested for five pathogens. At least one pathogen was molecularly detected in pigs at 63 (61.8\%) exhibitions. Influenza A virus was most prevalent and was detected in 498 (17.4\%) samples. Influenza D virus was detected in two (0.07\%) samples. More than one pathogen was detected in 165 (5.8\%) samples. Influenza A virus remains a top threat to animal and human health, but other pathogens may be disseminated through the exhibition swine population.
\end{abstract}

\section{Introduction, methods, and results}

Agricultural swine exhibitions showcase a variety of swine related educational programs, livestock auctions, and competitive shows for youth throughout the United States. Swine exhibitions are unique agricultural settings where large numbers of pigs from various geographic locales that would otherwise not come in contact with one another are co-housed and comingled for the length of the exhibition. Long exhibition durations (3-7 days), direct contact of swine, and relaxed biosecurity strategies have all been recognized as risk factors for the rapid transmission of infectious pathogens infecting swine during exhibitions $[1,2]$. Influenza A virus (IAV) has been routinely detected in swine at agricultural exhibitions, where subclinical infection is common and can make recognition difficult [3-6]. Swine are important mixing vessels of IAV, where genetic reassortment between multiple IAV strains may produce novel, potentially more virulent strains [7]. The comingling of large numbers of IAV

\footnotetext{
*Correspondence: bowman.214@osu.edu

1 Department of Veterinary Preventive Medicine, The Ohio State

University, 1920 Coffey Road, Columbus, OH 43210, USA

Full list of author information is available at the end of the article
}

infected swine at exhibitions may increase the chance for the emergence of these reassortant viruses.

In addition to the extensive interaction of swine, exhibitions also create a unique human-animal interface, where exhibiting families and the general public are permitted to interact with swine. This unique swine-human interface facilitates zoonotic transmission of IAVs during swine exhibitions [8]. Continued detection of variant IAVs, IAVs infecting humans that normally circulate in swine, in individuals who have association with swine exhibitions has begun to heighten disease awareness and surveillance in exhibition swine $[9,10]$. Combined with the ability of IAVs to reassort in swine, the increased swine-human interface of exhibitions creates opportunities for novel IAV strains to enter the human population, potentially leading to an influenza pandemic. Continued disease surveillance is vital to understanding the epidemiology of IAV and other pathogens infecting swine at agricultural exhibitions in order to protect animal and public health.

Commonly raised on small farms with varying management practices, the exhibition swine population is unlike commercial swine, which are managed in large herds 
under strict biosecurity protocols $[11,12]$. Coupled with extensive movement over a large geographic area in order to attend multiple exhibitions, exhibition swine facilitate the widespread dissemination of infectious pathogens throughout the country [11, 13]. Therefore, exhibition swine represent a unique niche in the total swine population that may play an important role in the ecology and epidemiology of all swine infectious diseases. With continued detection of IAV and increasing awareness of disease in exhibition swine, the current study aims to identify pathogens in addition to IAV that may be circulating in this swine population. Other swine respiratory viruses such as porcine hemagglutinating encephalomyelitis virus (PHEV), porcine reproductive and respiratory syndrome virus (PRRSV), porcine parainfluenza virus 1 (PPIV1), and influenza D virus (IDV) have only briefly been described in exhibition swine and their prevalence and overall impact in exhibition swine remains unknown $[12,14-16]$. With varying degrees of severity and impact on swine and human health, understanding the overall disease ecology and epidemiology of the exhibition swine population is vital to the development and implementation of disease mitigation strategies designed to protect animal and public health. Here, we describe the overall estimated prevalence of five infectious respiratory viruses in swine at agricultural exhibitions and assess the potential epidemiological role of exhibition swine.

In 2016, as part of an ongoing IAV surveillance program, 2862 pigs at 102 exhibitions across six states were sampled by nasal swab or nasal wipe $[17,18]$. All samples underwent nucleic acid extraction and were tested individually for IAV using real-time reverse transcription polymerase chain reaction (rRT-PCR) as previously described [19]. Five microliters of extracted nucleic acid of no more than seven individual pigs from the same exhibition were pooled and screened for PPIV1, PHEV, and IDV using rRT-PCR as previously described $[14,16$,
20] and for PRRSv using the VetMAX PRRSv reagents and manufacturer's protocol (ThermoFisher Scientific, Waltham, MA, USA). Nucleic acid of samples within positive pools was subsequently tested individually using the same methods.

During field sample collection, exhibitions with $\geq 1$ pig showing clinical signs consistent with influenza like illness (ILI) were recorded as having pigs with ILI [1]. Five of the exhibitions were excluded from statistical analysis due to lack of clinical sign data. Logistic regression (Stata special edition 14.2, College Station, TX, USA) was performed to determine any association between ILI noted at the exhibition and the detection of a pathogen in the pigs.

At least one pathogen was detected in the pigs at 63 (61.8\%) of the 102 swine exhibitions tested. Influenza A virus was detected among the pigs at $37(36.3 \%)$ and was detected at more exhibitions than any of the other viruses. In contrast, Influenza D virus was detected in the pigs at the fewest exhibitions; only pigs at two (2.0\%) of the exhibitions tested positive for IDV (Table 1). More than one pathogen was detected among the pigs at 31 (30.4\%) exhibitions; four pathogens were detected at three $(2.9 \%)$, representing the highest number of pathogens detected among the pigs at any of the exhibitions. Exhibitions with pigs testing positive for at least one pathogen had 2.4 times the odds of having noted ILI compared to exhibitions where no pathogens were detected $(p<0.05)$. Detection of IAV in swine at exhibitions was the only pathogen with a significant positive association to noted ILI at exhibitions $(\mathrm{OR}=1.3, p<0.05)$. However, with fewer positives, this association may be hidden for the other pathogens.

Out of the 2862 pigs sampled, 785 (27.4\%) tested positive for at least one pathogen. The most commonly detected pathogen was IAV which was detected in 498 (17.4\%) pigs. Influenza A virus was detected in more pigs

Table 1 Number of agricultural exhibitions with pigs testing positive for respiratory viruses by state

\begin{tabular}{|c|c|c|c|c|c|c|}
\hline State & Negative & IAV & PPIV1 & PHEV & PRRSv & IDV \\
\hline Ohio & 20 & 13 & 15 & 12 & 6 & 1 \\
\hline Indiana & 12 & 17 & 14 & 14 & 5 & 1 \\
\hline Michigan & 8 & 5 & 1 & 0 & 1 & 0 \\
\hline West Virginia & 1 & 0 & 0 & 0 & 0 & 0 \\
\hline Kentucky & 0 & 1 & 1 & 1 & 0 & 0 \\
\hline lowa & 0 & 1 & 1 & 1 & 1 & 0 \\
\hline Total & 41 & 37 & 32 & 28 & 13 & 2 \\
\hline
\end{tabular}

Individual swine nasal samples from 102 agricultural exhibitions across six states were tested for five respiratory viruses using real-time reverse transcription polymerase chain reaction. The number of swine exhibitions with $\geq 1$ pig positive for each pathogen are shown by state. Out of the 102 exhibitions tested, at least one pathogen was detected in the pigs at $63(61.8 \%)$. The pigs at $31(30.4 \%)$ exhibitions were positive for more than one virus.

IAV: influenza A virus, PPIV1: porcine parainfluenza virus 1, PHEV: porcine hemagglutinating encephalomyelitis, PRRSv: porcine reproductive and respiratory syndrome virus, IDV: influenza D virus. 
than the next two most prevalent pathogens combined, PHEV and PPIV1, which were detected in 251 (8.8\%) and 201 (7.0\%) pigs, respectively. Influenza D virus was the least prevalent and was only detected in two $(0.07 \%)$ pigs (Table 2). Co-infections were common with 165 (5.8\%) pigs testing positive for more than one pathogen, including four $(0.14 \%)$ pigs testing positive for three pathogens, which were the most pathogens found in co-infected, individual pigs.

\section{Discussion}

Due to widespread movement and prolonged intermingling, exhibition swine and the variety of pathogens they carry should be considered significant for both swine and human health. There has been increased attention on IAV in swine at exhibitions from veterinarians, health officials, and exhibition attendees due to recent IAV zoonotic transmission events [9, 21, 22]. Previous active surveillance has described the epidemiology of IAV in swine at exhibitions in the U.S.; at exhibitions where $\geq 1$ pig tests positive for IAV, over $60 \%$ of the pigs will have active IAV infection by the conclusion of the exhibition [3]. There were 18 cases of variant influenza infections associated with the IAVs detected in this population of exhibition swine, and IAV should remain a priority for infectious disease surveillance and mitigation in exhibition swine [22]. Several mitigation strategies have been suggested and implemented at exhibitions as the concern for animal and public health rises. Many of these strategies are aimed at reducing the risk of IAV transmission between pigs and humans before, during, and after agricultural swine exhibitions $[1,2]$. Still, IAV continues to impact exhibition swine and was detected at almost double the prevalence of PHEV, the next most prevalent virus of those included in this study.

\section{Table 2 Respiratory viruses detected in individual pigs at} agricultural exhibitions

\begin{tabular}{ll}
\hline $\begin{array}{l}\text { Pathogens detected in pigs } \\
\text { at exhibitions }\end{array}$ & $\begin{array}{l}\text { Number of pigs positive (\%) } \\
\boldsymbol{n = 2 8 6 2}\end{array}$ \\
\hline IAV & $498(17.4)$ \\
PHEV & $251(8.8)$ \\
PPIV1 & $201(7.0)$ \\
PRRSV & $20(0.7)$ \\
IDV & $2(0.07)$
\end{tabular}

Individual swine nasal samples from 102 agricultural exhibitions were tested for five respiratory viruses by real-time reverse transcription polymerase chain reaction. The number of individual pigs positive for each pathogen are shown. Seven hundred eighty-five pigs tested positive for at least one pathogen. Of those, 165 pigs tested positive for $>1$ pathogen.

IAV: influenza A virus, PPIV1: porcine parainfluenza virus 1, PHEV: porcine hemagglutinating encephalomyelitis, PRRSv: porcine reproductive and respiratory syndrome virus, IDV: influenza D virus.
Despite the persistent spread of IAV through exhibition swine and its implications for both animal and human health, other infectious pathogens can be detected in exhibition swine and should not be ignored. Identification of active infections in exhibition swine is vital to protecting animal and human health during agricultural exhibitions. Pigs at exhibitions with at least one pathogen detected in the pigs were more likely to exhibit ILI. However, subclinical infections are common and there is overlap in clinical signs associated with various respiratory pathogens in swine; because of this, clinical signs should not be solely relied upon for the detection and subsequent diagnosis of infectious pathogens in swine at exhibitions [3, 6]. Proper biosecurity should be used at all times, even in the absence of clinical signs, in order to reduce the risk of intra- and interspecies transmission of all pathogens during exhibitions.

Focus on animal and public health at swine exhibitions is a priority, but the potential for introduction of infectious pathogens from exhibition swine into commercial swine facilities should also be considered. An estimated $39 \%$ of exhibition pigs are raised near commercial swine, with many of those returning home after attending an exhibition [12]. Detection of pathogens such as PHEV and PRRSv in exhibition swine raises concern for commercial swine due to the potential economic implications should they enter the production system. PRRSv alone causes an estimated $\$ 600$ million in economic loses annually in the United States swine production system [23]. Detection of PPIV1 and IDV also raises concern, though they are more recently described in swine and their overall consequences to swine health are still unknown $[15,16]$.

In addition to the five pathogens assessed in the present study, there is potential for other pathogens to travel with and spread through exhibition swine that may also present a threat to commercial swine, including foreign animal-diseases. Exhibition swine should not be disregarded as potential hosts and disseminators of diseases such as African swine fever virus (ASFV); movement and comingling of pigs have been recognized as risk factors for the spread of ASFV in endemic regions [24]. If overlooked, exhibition pigs may create a niche for devastating pathogens, with extensive animal movement resulting in rapid spread across the country. The findings of this study highlight the potential role of exhibition swine in the disease ecology and epidemiology of the United States swine population. Lack of sustained disease surveillance and application of mitigation strategies for swine at agricultural exhibitions will allow for continued variant IAV infections that pose considerable risk to public health and could ultimately lead to a devastating disease epizootic within the U.S. swine herd. 


\section{Abbreviations}

IAV: influenza A virus; PHEV: porcine hemagglutinating encephalomyelitis virus; PPIV1: porcine parainfluenza virus 1; PRRSv: porcine reproductive and respiratory syndrome virus; IDV: influenza D virus; rRT-PCR: real-time reverse transcription polymerase chain reaction; ILI: influenza like illness.

\section{Acknowledgements}

The authors would like to thank field staff Michele Zentkovich, Alison Martin, Courtney Wright, Lauren Smith, and Alex Tweedy for collection of the samples as well as research assistants Rachel Patton, Libby McGarry and Dillon McBride for help in the laboratory. We also thank the exhibition officials and participants for partaking in the study. Funding was provided by the Centers of Excellence for Influenza Research and Surveillance, National Institute of Allergy and Infectious Diseases, National Institutes of Health, Department of Health and Human Services, under Contract Nos. HHSN266200700007C and HHSN272201400006C.

\section{Authors' contributions}

SEL: Data analysis, data interpretation, manuscript preparation. SWN: Laboratory sample testing, data analysis, manuscript preparation. MER: Study design, laboratory sample testing, data analysis, manuscript revision. JNL: Study design, data interpretation, manuscript revision. JMN: Study design, data interpretation, manuscript revision. ASB: Study conception and design, data interpretation, manuscript revision. All authors read and approved the final manuscript.

\section{Funding}

Funding was provided by the Centers of Excellence for Influenza Research and Surveillance, National Institute of Allergy and Infectious Diseases, National Institutes of Health, Department of Health and Human Services, under Contract Nos. HHSN266200700007C and HHSN272201400006C.

\section{Availability of data}

All data generated or analyzed during this study are included in this published article.

\section{Ethics approval and consent to participate}

Ethics approval for animal use in this research was provided by the Institutional Animal Care and Use Committee at the Ohio State University under Approval Number 2009A0134-R2.

\section{Competing interests}

The authors declare that they have no competing interests.

\section{Author details}

${ }^{1}$ Department of Veterinary Preventive Medicine, The Ohio State University, 1920 Coffey Road, Columbus, OH 43210, USA. ${ }^{2}$ Present Address: Health Science District, University of California Davis, 1 Garrod Drive, Davis, CA 95616 , USA.

Received: 12 July 2019 Accepted: 27 August 2019 Published online: 18 September 2019

\section{References}

1. Bowman AS, Workman JD, Nolting JM, Nelson SW, Slemons RD (2014) Exploration of risk factors contributing to the presence of influenza $A$ virus in swine at agricultural fairs. Emerg Microbes Infect 3:e5

2. National Association of State Public Health Veterinarians. Measures to minimize influenza transmission at swine exhibitions (2018) http://www. nasphv.org/Documents/InfluenzaTransmissionAtSwineExhibitions2018. pdf. Accessed 1 June 2019

3. Bowman AS, Nolting JM, Nelson SW, Slemons RD (2012) Subclinical influenza virus $A$ infections in pigs exhibited at agricultural fairs, Ohio, USA, 2009-2011. Emerg Infect Dis 18:1945-1950

4. Vincent AL, Swenson SL, Lager KM, Gauger PC, Loiacono C, Zhang Y (2009) Characterization of an influenza A virus isolated from pigs during an outbreak of respiratory disease in swine and people during a county fair in the United States. Vet Microbiol 137:51-59
5. Killian ML, Swenson SL, Vincent AL, Landgraf JG, Shu B, Lindstrom S, Xu X, Klimov A, Zhang Y, Bowman AS (2013) Simultaneous infection of pigs and people with triple-reassortant swine influenza virus H1N1 at a U.S. county fair. Zoonoses Public Health 60:196-201

6. Corzo CA, Culhane M, Juleen K, Stigger-Rosser E, Ducatez MF, Webby RJ, Lowe JF (2013) Active surveillance for influenza A virus among swine, midwestern United States, 2009-2011. Emerg Infect Dis 19:954-960

7. Ma W, Kahn RE, Richt JA (2008) The pig as a mixing vessel for influenza viruses: human and veterinary implications. J Mol Genet Med 3:158-166

8. Nelson MI, Wentworth DE, Das SR, Sreevatsan S, Killian ML, Nolting JM, Slemons RD, Bowman AS (2016) Evolutionary Dynamics of influenza A viruses in US exhibition swine. J Infect Dis 213:173-182

9. Schicker RS, Rossow J, Eckel S, Fisher N, Bidol S, Tatham L, MatthewsGreer J, Sohner K, Bowman AS, Avrill J, Forshey T, Blanton L, Davis CT, Schiltz J, Skorupski S, Berman L, Jang Y, Bresee JS, Lindstrom S, Trock SC, Wentworth D, Fry AM, Fijter Sd, Signs K, DiOrio M, Olsen SJ, Biggerstaff M (2016) Outbreak of Influenza A(H3N2) variant virus infections among persons attending agricultural fairs housing infected swine-Michigan and Ohio, July-August 2016. MMWR Morb Mortal Wkly Rep 65:1157-1160

10. Wong KK, Greenbaum A, Moll ME, Lando J, Moore EL, Ganatra R, Biggerstaff M, Lam E, Smith EE, Storms AD, Miller JR, Dato V, Nalluswami K, Nambiar A, Silvestri SA, Lute JR, Ostroff S, Hancock K, Branch A, Trock SC, Klimov A, Shu B, Brammer L, Epperson S, Finelli L, Jhung MA (2012) Outbreak of influenza $A(H 3 N 2)$ variant virus infection among attendees of an agricultural fair, Pennsylvania, USA, 2011. Emerg Infect Dis 18:1937-1944

11. Bliss N, Stull JW, Moeller SJ, Rajala-Schultz PJ, Bowman AS (2017) Movement patterns of exhibition swine and associations of influenza $A$ virus infection with swine management practices. J Am Vet Med Assoc 251:706-713

12. Wayne SR, Morrison RB, Odland CA, Davies PR (2012) Potential role of noncommercial swine populations in the epidemiology and control of porcine reproductive and respiratory syndrome virus. J Am Vet Med Assoc 240:876-882

13. Nelson MI, Stucker KM, Schobel SA, Trovao NS, Das SR, Dugan VG, Nelson SW, Sreevatsan S, Killian ML, Nolting JM, Wentworth DE, Bowman AS (2016) Introduction, evolution, and dissemination of influenza A viruses in exhibition swine in the United States during 2009 to 2013. J Virol 90:10963-10971

14. Lorbach JN, Wang L, Nolting JM, Benjamin MG, Killian ML, Zhang Y, Bowman AS (2017) Porcine hemagglutinating encephalomyelitis virus and respiratory disease in exhibition swine, Michigan, USA, 2015. Emerg Infect Dis 23:1168-1171

15. Thielen P, Nolting JM, Nelson SW, Mehoke TS, Howser C, Bowman AS (2019) Complete genome sequence of an influenza D virus strain identified in a pig with subclinical infection in the United States. Microbiol Resour Announc 8:e01462

16. Palinski RM, Chen Z, Henningson JN, Lang Y, Rowland RR, Fang Y, Prickett J, Gauger PC, Hause BM (2016) Widespread detection and characterization of porcine parainfluenza virus 1 in pigs in the USA. J Gen Virol 97:281-286

17. Nolting JM, Szablewski CM, Edwards JL, Nelson SW, Bowman AS (2015) Nasal wipes for influenza A virus detection and isolation from swine. J Vis Exp. (106):e53313

18. Edwards JL, Nelson SW, Workman JD, Slemons RD, Szablewski CM, Nolting JM, Bowman AS (2014) Utility of snout wipe samples for influenza A virus surveillance in exhibition swine populations. Influenza Other Respir Viruses 8:574-579

19. Bliss N, Nelson SW, Nolting JM, Bowman AS (2016) Prevalence of influenza A virus in exhibition swine during arrival at agricultural fairs. Zoonoses Public Health 63:477-485

20. Hause BM, Ducatez M, Collin EA, Ran ZG, Liu RX, Sheng ZZ, Armien A, Kaplan B, Chakravarty S, Hoppe AD, Webby RJ, Simonson RR, Li F (2013) Isolation of a novel swine influenza virus from Oklahoma in 2011 which is distantly related to human influenza C viruses. PLoS Pathog 9:e1003176

21. Alsup B (2018) Two cases of flu linked to contact with swine at Fowlerville fair. The Detroit News

22. Bowman AS, Walia RR, Nolting JM, Vincent AL, Killian ML, Zentkovich MM, Lorbach JN, Lauterbach SE, Anderson TK, Davis CT, Zanders N, Jones J, Jang Y, Lynch B, Rodriguez MR, Blanton L, Lindstrom SE, Wentworth DE, Schiltz J, Averill JJ, Forshey T (2017) Influenza A(H3N2) virus in swine at 
agricultural fairs and transmission to humans, Michigan and Ohio, USA, 2016. Emerg Infect Dis 23:1551-1555

23. Holtkamp DJ, Kliebenstein JB, Neumann EJ, Zimmerman JJ, Rotto HF, Yoder TK, Wang C, Yeske PE, Mowrer CL, Haley CA (2013) Assessment of the economic impact of porcine reproductive and respiratory syndrome virus on United States pork producers. J Swine Health Prod 21:72-84

24. Costard S, Zagmutt FJ, Porphyre T, Pfeiffer DU (2015) Small-scale pig farmers' behavior, silent release of African swine fever virus and consequences for disease spread. Sci Rep 5:17074

\section{Publisher's Note}

Springer Nature remains neutral with regard to jurisdictional claims in published maps and institutional affiliations.
Ready to submit your research? Choose BMC and benefit from:

- fast, convenient online submission

- thorough peer review by experienced researchers in your field

- rapid publication on acceptance

- support for research data, including large and complex data types

- gold Open Access which fosters wider collaboration and increased citations

- maximum visibility for your research: over 100M website views per year

At BMC, research is always in progress.

Learn more biomedcentral.com/submissions 